\title{
Canto Transitional 1 (Gluttonous to Lustful)
}

Lifting the valley tableau, a mirror eyeing the swift shade's crossing, drag of body: hunger, longing,

sight worn past sockets, a favored object worn away and flesh wearing away

with it; and so to crossing up, as red as spectrum will allow, collective memory recognize:

that sun at our shoulder, scorpions burrowing under lichenencrusted granite, rose quartz chunks;

beetles' carapaces hang on a thread, and a cushion of green emulsifies stubble sharp enough to puncture rubber soles.

How quickly you move across the reliquary of invertebrates, a solitary pink and grey pecking at seed swept onto firebreak:

its curl of beak gurgling with the piston nub of its tongue, husks falling into shade that won't leave it alone,

won't take notice of its irritable twitch of head or wing, scratching to tear into light. It's whispered that across the road 
they invite friends to watch dogs copulating, getting stuck into it. Between here and there the remnant York gums, shells of exfoliated

granite bearings, cyclone wire twisted, claws inwards, about the base of older specimens: uncut grass in there, cauterized

wire where the nylon of the whipper snipper has lashed, broken off, fallen like catechesis uttered out of habit-you recognize strike,

tussle, and after the snapping, higher revs of the device's motor; fruit on the house trees has set and fallen-a season away from harvest.

To barrier the outside, to clarify inside property boundaries where loyalty is familiar, custodial, tree lucerne-Tagasaste-planted, walling

in quickly...an earlier resistance brought down by a flock of rescue sheep, their blackness culling from a herd of whiteness...

ring-barking tree lucerne to a deciduousness of shade, unmoved by a strong sea-breeze cutting up over scarp from concave waters,

driving against fire, heat of an emptied inland. So, walking hard again, and thinking out loud, our three-year-old marvels at movement

of shade: so slow beneath jam trees when he's standing beneath or beside foliage, yet vastly different walking in morning, 
at midday, or evening...; in walking, a wariness pervades-dugites, gwarders, red-back tripwires coming down

from veranda eaves, from old power pole fence-posts, scorpions under rocks inviting to sit on, turn over idly-a destructive curiosity,

habitats bashed, adapted-scats of silent animals, fullness of darkness that makes visible a density in loss: fox,

rabbit, cat, field mice, hopping mice, even rare marsupials struggling among York gums, up high; owl pellets.

The child walks free of gluttony and lust, but spray-drift of mosquito poison, coating storm-fluids, conditions him

for a life of negotiations, tolerance, loss.

The joy of the walk is lost, but we still smile, and amuse him, and share as many names

as we can. Again: "It's so beautiful," he says. A trio of ring-necked parrots darts up onto the limb of the dead tree semi-arched towards the driveway: they call with an energy to match his enthusiasm. They depart suddenly: alarmed, joyful, possessed, enraptured? 